\title{
Somatostatin Receptor Scintigraphy: Its Value in Tumor Localization in Patients with Cushing's Syndrome Caused by Ectopic Corticotropin or Corticotropin-Releasing Hormone Secretion
}

\author{
Wouter W. de Herder, m.D., Eric P. Krenning, M.D., Carl D. Malchoff, m.d., Leo J. Hofland, Ph.D., \\ Jean-Claude Reubl, M.D., Dik J. KWekKeboom, M.D., H. Yoe Oel, M.D., HulBert A.P. Pols, M.D., \\ Hajo A. Bruining, M.D., Frank R.E. Nobels, M.D., Steven W.J. LamBERTS, M.D., Rotterdam, the Netherlands
}

\begin{abstract}
PURPOSE: To assess the feasibility of somatostatin receptor scintigraphy for patients with Cushing's syndrome caused by tumors secreting ectopic corticotropin or corticotropin-releasing hormone (CRH).
\end{abstract}

PATIENTS AND METHODS: Ten patients with Cushing's syndrome, nine with ectopic corticotropinsecreting tumors and one with a CRH-secreting tumor, were consecutively studied. For comparison purposes, eight patients with corticotropin-secreting pituitary tumors and one patient with an autonomous adrenal adenoma were investigated. In vivo tumor localization was performed for all patients using a radionuclidecoupled somatostatin analog. The results obtained with this technique were compared with those obtained with conventional imaging techniques. For some patients, the clinical effects of octreotide therapy were evaluated. RESULTS: Somatostatin analog scintigraphy successfully identified the primary ectopic corticotropin-secreting and $\mathrm{CRH}$-secreting tumors or their metastases, or both, in $\mathbf{8}$ of 10 patients; in 2 patients with corticotropin-secreting bronchial carcinoids, the tumors could not be visualized. Normal scans were obtained for the 8 patients with corticotropin-secreting pituitary tumors and the one patient with an adrenal adenoma.

CONCLUSION: Somatostatin analog scintigraphy can be included as a diagnostic step in the workup of Cushing's syndrome patients with a suspected ectopic corticotropin-secreting tumor or a CRHsecreting tumor.

From the Department of Internal Medicine III (WWDH, HAPP, LJH, SWJL), Department of Nuclear Medicine (EPK, DJK, HYO), Department of

Surgery (HAB), University Hospital Dijkzigt, Rotterdam, the Netherlands; Department of Surgery (CDM), Surgical Research Center, University of Connecticut Health Center, Farmington, Conn.; Division of Cell Biology and Experimetnal Cancer Research (JCR), Institutue of Pathology,

University of Bern, Bern, Switzerland; Department of Internal Medicine

(FREN), Onze Lieve Vrouw Hospital, Aalst, Belgium.

Requests for reprints should be addressed to Wouter W. de Herder, MD, Department of Internal Medicine III, University I lospital Dijkzigt, Dr.

Molewaterplein 40, 3015 GD Rotterdam, the Netherlands.

Manuscript submitted February 15, 1993, and accepted in revised form Junc 17, 1993.
T umorous secretion of peptides derived from proopiomelanocortin, including biologically active corticotropin, is one of the many humoral syndromes of cancer. It accounts for about $15 \%$ to $20 \%$ of cases of Cushing's syndrome from all causes. ${ }^{1,2}$ Medullary thyroid carcinomas, small cell lung cancers, carcinoids, pancreatic islet cell tumors, pheochromocytomas, and paragangliomas account for approximately $80 \%$ of the cases. For the majority of patients with ectopic corticotropin secretion, the typical Cushing's syndrome habitus is absent. The clinical picture is typified by the sudden appearance and rapid progression of signs of extreme hypercortisolemia, including hypertension, edema, weakness, hypokalemia, and glucose intolerance; plasma corticotropin concentrations are often very high and may be associated with hyperpigmentation. These signs may be accompanied by manifestations of the malignancy causing the hypercortisolism. In patients with occult tumors, however, differentiating between an ectopic and a pituitary source of corticotropin may be difficult. 3,4

Long-term therapy with the somatostatin analog octreotide for patients with carcinoids, pancreatic islet cell tumors, and medullary thyroid carcinomas has been reported to control hormonal hypersecretion, improve symptomatology, and in some cases, reduce tumor growth. Corticotropin secretion of pituitary-dependent Cushing's syndrome (Cushing's disease) usually does not respond to octreotide, but the agent has been successfully used to control ectopic corticotropin secretion caused by neuroendocrine tumors. ${ }^{5-7}$ Visualization of somatostatin-receptor-positive tumors in vivo after intravenous injection of $\left[{ }^{123} \mathrm{I}-\mathrm{Tyr}^{3}\right]$-octreotide or [ ${ }^{111} \mathrm{In}$-DTPA-DPhe $\left.^{1}\right]$-octreotide has been successful with a number of human tumors. . $^{8-10}$

We report our experience with somatostatin receptor scintigraphy for 10 patients with Cushing's syndrome and clinical evidence of ectopic corticotropin production or tumors secreting corticotropin-releasing hormone, and for 5 patients with Cushing's disease, 3 patients with Nelson's syndrome, and 1 patient with Cushing's syndrome caused by an adrenal adenoma. The clinical response to octreotide 


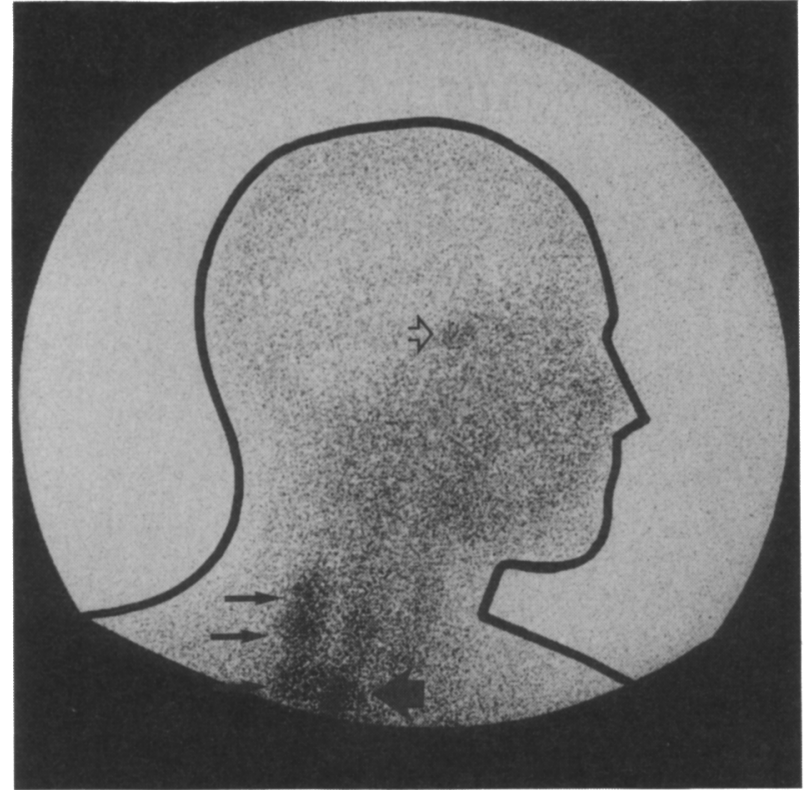

Figure 1. Lateral image of the head and neck of patient 1,24 hours after injection of [ ${ }^{111}$ In-DTPA-D-Phe ${ }^{1]}$-octreotide. Note the asymmetrical accumulation of radioactivity in the thyroid (large arrow) and in the lymph node metastases lateral to the right thyroid lobe (small arrows), whereas accumulation in the pituitary is normal (open arrow).

therapy was studied in 7 patients with Cushing's syndrome caused by ectopic corticotropin or CRH secretion. Tumor samples of 6 patients were examined for somatostatin analog-binding sites by in vitro autoradiography with $\left[{ }^{125} \mathrm{I}-\mathrm{Tyr}^{3}\right]$-octreotide.

\section{METHODS}

The somatostatin analogs [ $\left.\mathrm{Tyr}^{3}\right]$-octreotide and [DTPA-D-Phe ${ }^{1}$-octreotide (Sandoz, Basel, Switzerland) were labeled with ${ }^{123} \mathrm{I}$ and ${ }^{111} \mathrm{In}$, respectively, as described elsewhere. ${ }^{11,12}$ The scintigraphic technique used with these compounds to visualize somatostatin-receptor-positive tumors has been described previously. ${ }^{810,13,14}$ In vivo receptor imaging with [ ${ }^{123} \mathrm{I}-\mathrm{Tyr}^{3}$ ]-octreotide has drawbacks: The availability of chemically pure ${ }^{123} \mathrm{I}$ is limited, it has a rather short half-life, and its predominant hepatobiliary clearance makes recognizing abdominal tumors difficult. Most of these negative aspects have been overcome by replacing $\left[{ }^{123}\left[-\mathrm{Tyr}^{3}\right]\right.$-octreotide with $\left[{ }^{111} \mathrm{In}\right.$ DTPA-D-Phe ${ }^{1}$-octreotide. ${ }^{10-12}$ In the present study we initially used $\left[{ }^{123}\left[-\mathrm{Tyr}^{3}\right]\right.$-octreotide with two patients, but when [ ${ }^{111}$ In-DTPA-D-Phe $\left.{ }^{1}\right]$-octreotide became available to us, we used it with all other patients.

Somatostatin analog-binding sites were also determined in vitro by autoradiography on cryostat sections of the tumor tissues of five patients, as described before. ${ }^{13}$

Serum and urinary cortisol were measured by radioimmunoassay (Diagnostic Products Corporation, Los Angeles, California). Since tumors producing cor-

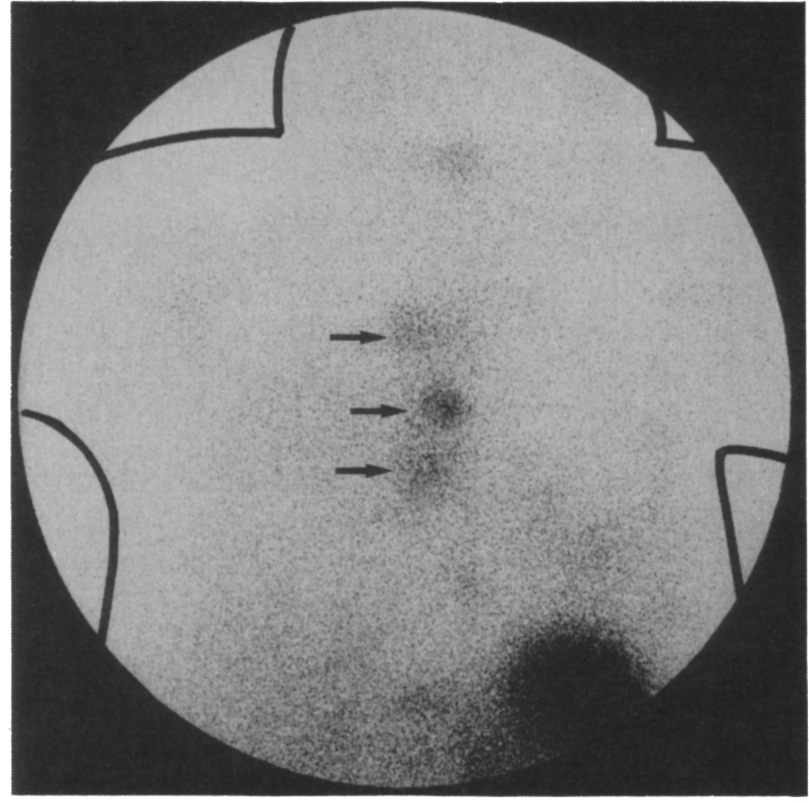

Figure 2. Anterior image of the chest of patient 4, 24 hours after injection of [ ${ }^{11} \mid \mathrm{n}$-DTPA-D-Phe ${ }^{1}$-octreotide. Note the accumulation of radioactivity in the mediastinal lymph node metastases (arrows), whereas uptake in the liver, kidneys, and spleen is normal.

ticotropin ectopically may also produce "big" corticotropin or biologically active fragments of corticotropin, or both, we preferred to measure plasma corticotropin $\left(\mathrm{ACTH}_{1-39}\right)$ by radioimmunoassay (Medgenix, Fleurus, Belgium) rather than by the more specific two-site immunoradiometric assay. Corticotropin-releasing hormone ${ }_{41}$ was measured by immunoradiometric assay (Dr E.A. Linton, Department of Biochemistry and Physiology, University of Reading School of Animal and Microbial Sciences, Reading, UK).

In all cases, the diagnosis was confirmed by histologic examination of stained tissue sections. Preparations from seven patients were also studied by immunohistochemistry using an anticorticotropin antiserum. Tumor cells of two patients were cultured according to previously described methods. ${ }^{14}$

All patients gave informed consent to participate in this study, which was approved by the ethics committee of our hospital.

\section{RESULTS}

\section{Clinical, Biochemical, and Pathologic Features}

The diagnosis of Cushing's syndrome was suspected for all 10 patients by their clinical presentation and was subsequently confirmed by endocrinologic testing. Serum cortisol levels were elevated in all patients and were suppressed insufficiently in response to $1 \mathrm{mg}$ dexamethasone in nine of the patients studied. Urinary cortisol excretion and serum corticotropin levels were also increased in all patients 


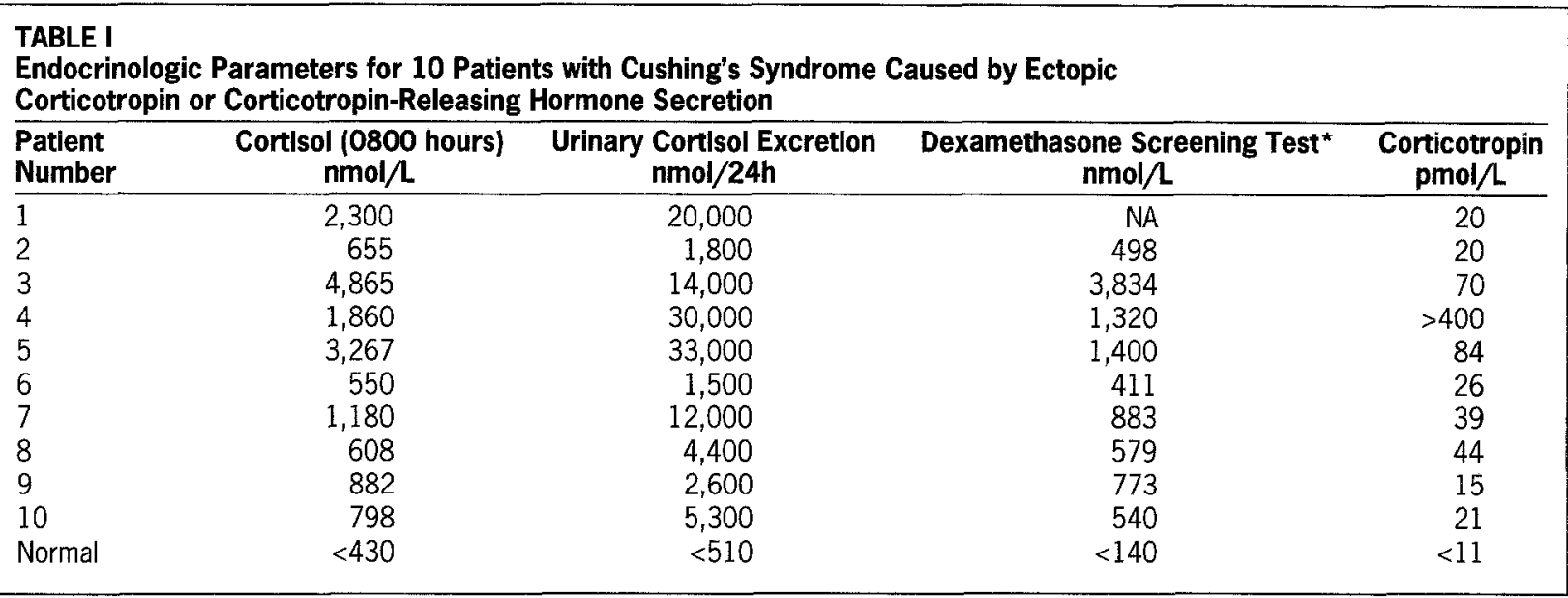

${ }^{*}$ Serum cortisol at 8:00 AM, after oral administration of $1 \mathrm{mg}$ dexamethasone at 11:00 PM the previous evening. $N A=$ not available.

(Table I). Six patients had hypokalemia, which was not related to the use of diuretics. Five patients had hypertension (systolic blood pressure greater than $160 \mathrm{~mm} \mathrm{Hg}$ or diastolic blood pressure greater than $90 \mathrm{~mm} \mathrm{Hg}$ ). Four patients had glucose intolerance (as defined by random venous plasma glucose levels of $11.1 \mathrm{mmol} / \mathrm{L}$ or higher).

Metastatic (sporadic) medullary thyroid carcinoma was diagnosed in patients 1,2 , and 3 (Table II). Tumor biopsies from these three patients did not stain positively for corticotropin. In patient 1 , however, cultured tumor cells prepared from a cervical lymph node metastasis showed $380 \mathrm{pg} \mathrm{CRH} / 10^{6}$ cells but no corticotropin. Corticotropin and CRH levels in the conditioned medium from the cultured tumor cells were below the detection limit of the assay used. These results suggest this tumor was ectopically producing $\mathrm{CRH}$ rather than corticotropin.

A bone marrow smear from patient 4 showed a diffusely infiltrating anaplastic small cell carcinoma, and based on additional clinical and radiologic data, small cell lung cancer was diagnosed. In patients 5 and 10 , solitary bronchial carcinoids $1.5 \mathrm{~cm}$ and $1.8 \mathrm{~cm}$ in diameter, respectively, were removed at thoracotomy. In both cases, no lymph node enlargement was detected. In patient 6 , a corticotropin-producing bronchial carcinoid was removed 3-1/2 years before Cushing's syndrome clinically recurred; a bronchial carcinoid recurrence was suspected, but no tumor localizations were detected. In patient 7 , resection of a bronchial carcinoid and two paraesophageal lymph node metastases resulted in transient remission of Cushing's syndrome. A metastatic thymic carcinoid was found in patient 8 , and a metastatic pancreatic gastrinoma was diagnosed in patient 9 . Tumor tissue from patients $5,7,9$, and 10 contained immunoreactive corticotropin, strongly suggesting that the tumors were the source of the hormone. Immunohistochemistry of tumor tissue from patient 8 did not show positive staining for corticotropin, but cultured tumor cells produced small amounts of corticotropin.

\section{Scintigraphic and Radiographic Evaluation}

Octreotide scintigraphy demonstrated uptake of the radionuclide-coupled somatostatin analog in several tumor localizations-also identified by abdomen and thorax computerized tomography (CT), neck and abdomen ultrasonography, and bone scintigraphy (Table II)-for patients 1, 2, and 3 with metastatic medullary thyroid carcinoma. Tumor localizations in the liver of all three patients and in a retroperitoneal lymph node in patient 1 were not detected by octreotide scintigraphy (Figure 1, Table II). Octreotide scintigraphy did show abnormal uptake in the mediastinum, the bony pelvis, the lumbar spine, and the proximal femoral bone of patient 4 with small cell lung cancer (Figure 2). Routine chest roentgenography of this patient did not show abnormalities; bone scintigraphy was normal; and a CT scan of the chest identified mediastinal lymphadenopathy but the primary lung tumor was not seen.

Patient 5 had a solitary bronchial carcinoid, shown on chest roentgenogram and CT scan as a single intrapulmonary mass in the right middle lobe. Octreotide scintigraphy did not show pathologic uptake of the radiopharmaceutical. In patient 6 , who had Cushing's syndrome recurrence after removal of a corticotropin-producing bronchial carcinoid, no metastatic carcinoid lesion could be identified by CT scanning or by magnetic resonance (MR) imaging of the chest. Octreotide scintigraphy was negative for this patient, and the localization of tumor tissue is still unknown.

Patient 7 had a metastatic bronchial carcinoid, and octreotide scintigraphy demonstrated uptake in the left lower lobe of the lung and in the mediastinum (Figure 3A). A contrast-enhanced CT scan of the thorax with attention to the left lower lobe identified a 


\begin{tabular}{|c|c|c|c|c|c|c|c|}
\hline $\begin{array}{l}\text { Patient } \\
\text { Number }\end{array}$ & $\begin{array}{l}\text { Age } \\
\text { (Y) }\end{array}$ & Sex & Diagnosis & $\begin{array}{c}\text { Tumor } \\
\text { Localizations* }\end{array}$ & $\begin{array}{c}\text { Octreotide } \\
\text { Scintigraphy }\end{array}$ & $\begin{array}{c}\text { In vitro } \\
\text { Autoradiography }\end{array}$ & $\begin{array}{l}\text { In vivo Response } \\
\text { to Octreotide }\end{array}$ \\
\hline 1 & 38 & $M$ & MTC & $\begin{array}{c}\text { Thyroid } \\
\text { Neck } \\
\text { Liver } \\
\text { Retroperitoneal node }\end{array}$ & $\begin{array}{l}+ \\
+ \\
- \\
-\end{array}$ & $\begin{array}{c}\text { NA } \\
+ \\
- \\
-\end{array}$ & $\begin{array}{l}\text { Plasma corticotropin } \\
\text { decreased by } 41 \%\end{array}$ \\
\hline 2 & 45 & $\mathrm{~F}$ & MTC & $\begin{array}{c}\text { Bone } \\
\text { Neck } \\
\text { Supraclavicular (L) } \\
\text { Lungs } \\
\text { Mediastinum } \\
\text { Liver }\end{array}$ & $\begin{array}{l}+ \\
+ \\
+ \\
+ \\
+ \\
-\end{array}$ & $\begin{array}{l}\text { NA } \\
- \\
\text { NA } \\
\text { NA } \\
\text { NA } \\
\text { NA }\end{array}$ & NA \\
\hline 3 & 35 & M & MTC & $\begin{array}{c}\text { Neck } \\
\text { Lungs } \\
\text { Mediastinum } \\
\text { Liver }\end{array}$ & $\begin{array}{l}+ \\
+ \\
+ \\
+\end{array}$ & $\begin{array}{l}\text { NA } \\
\text { NA } \\
\text { NA } \\
\text { NA }\end{array}$ & $\begin{array}{l}\text { Plasma corticotropin } \\
\text { decreased by } 60 \%\end{array}$ \\
\hline 4 & 61 & $\mathrm{~F}$ & SCLC & $\begin{array}{l}\text { Mediastinum } \\
\text { Bone marrow }\end{array}$ & $\begin{array}{l}+ \\
+\end{array}$ & $\begin{array}{l}\text { NA } \\
\text { NA }\end{array}$ & $\begin{array}{l}\text { Urinary cortisol } \\
\text { excretion decreased } \\
\text { by } 54 \%\end{array}$ \\
\hline 5 & 65 & M & Carcinoid & Right middle lobe lung & - & NA & NA \\
\hline 6 & 36 & $\mathrm{~F}$ & Carcinoid & Unknown localization & - & NA & No response \\
\hline 7 & 26 & $F$ & Carcinoid & $\begin{array}{l}\text { Left lower lobe lung } \\
\text { Paraesophageal nodes }\end{array}$ & $\begin{array}{l}+ \\
+\end{array}$ & $\begin{array}{l}+ \\
+\end{array}$ & $\begin{array}{l}\text { Plasma corticotropin } \\
\text { decreased by } 30 \%\end{array}$ \\
\hline 8 & 35 & $\mathrm{~F}$ & Carcinoid & $\begin{array}{c}\text { Thymus } \\
\text { Mediastinal nodes }\end{array}$ & $\begin{array}{l}+ \\
+\end{array}$ & $\stackrel{+}{N A}$ & $\begin{array}{l}\text { Plasma corticotropin } \\
\text { decreased by } 88 \%\end{array}$ \\
\hline 9 & 37 & M & Gastrinoma & $\begin{array}{l}\text { Pancreas ( } 2 \text { tumors) } \\
\text { Lymph node }\end{array}$ & $\begin{array}{l}+ \\
+\end{array}$ & $\begin{array}{l}+ \\
+\end{array}$ & $\begin{array}{l}\text { Plasma corticotropin } \\
\text { and urinary cortisol } \\
\text { excretion normalized }\end{array}$ \\
\hline 10 & 42 & $M$ & Carcinoid & Left lower lobe lung & + & + & NA \\
\hline
\end{tabular}

* Known by physical examination, radiologic techniques, surgery, or autopsy.

$N A=$ not available; MTC = medullary thyroid carcinomas; $S C L C=$ small cell lung cancer .

$10 \times 15 \mathrm{~mm}$ lesion in the left lower lobe of the lung but no mediastinal lymphadenopathy (Figure $3 \mathrm{~B}$ ). Review of the CT scan performed 6 months earlier revealed a $5 \times 8 \mathrm{~mm}$ lesion at the same location that could not be distinguished from blood vessels cut at an oblique angle, since they were of similar size.

In patient 8, a CT scan of the chest showed a nonhomogeneous tumor mass within the anterior mediastinum and enlarged paratracheal lymph nodes. A CT scan of the abdomen was normal, but octreotide scintigraphy demonstrated uptake in a large mediastinal mass (Figure 4). In patient 9, octreotide scintigraphy indicated three tumors in the region of the pancreas; no abnormalities in liver uptake were seen. Computerized tomography revealed a tumor in the corpus of the pancreas as well as an enlarged lymph node in the liver hilus, but no detectable liver metastases. ${ }^{14}$ Patient 10 had a solitary bronchial car- cinoid. A chest roentgenogram was normal, but octreotide scintigraphy showed uptake in the left lower lobe of the lung; a contrast-enhanced CT scan of the thorax with attention to the left lower lobe revealed a solitary $12 \times 18 \mathrm{~mm}$ lesion there.

\section{Autoradiography}

In vitro somatostatin receptor autoradiography was performed on tumor samples from patients 1,2 , $7,8,9$, and 10 . In vitro, a cervical lymph node metastasis sample from patient 1 , who had metastatic medullary thyroid carcinoma, contained somatostatin analog-binding sites, whereas abdominal lymph node metastasis and liver metastasis samples from the same patient were negative (Figure 5). A cervical lymph node metastasis sample from patient 2 was also negative. High numbers of somatostatin analogbinding sites were present in tumor samples from the 

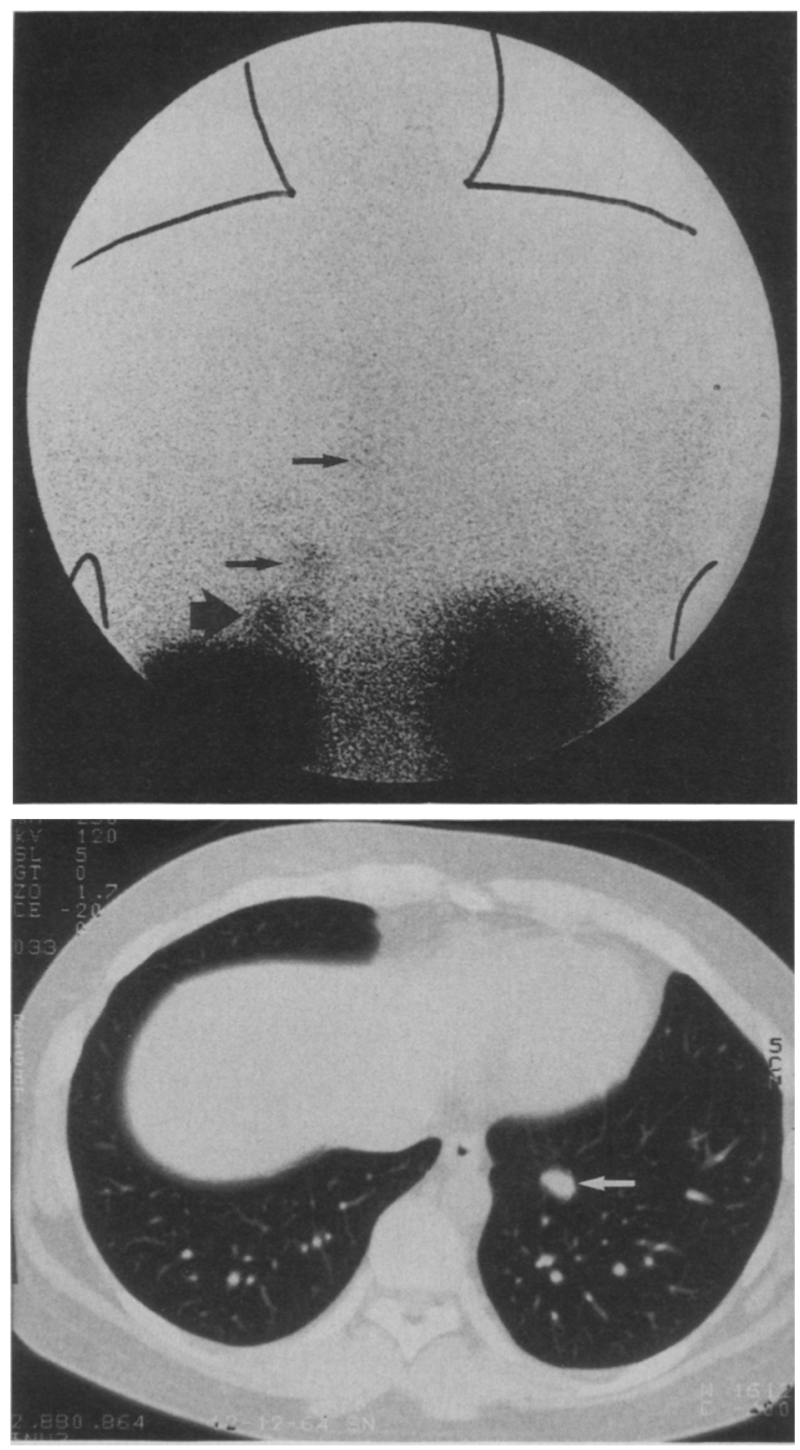

Figure 3. Posterior image of the chest of patient 7,24 hours after injection of [ ${ }^{11}$ In-DTPA-D-Phe ${ }^{1}$-octreotide $(\mathbf{A})$. Note the accumulation of radioactivity in the left lower lobe of the lung (large arrow) and the mediastinum (small arrows). Computed tomography scan of the chest of the same patient (B) shows a 15 $x 10 \mathrm{~mm}$ lesion in the left lower lobe of the lung (arrow)

metastatic bronchial carcinoid of patients 7 and 10 and from the thymic carcinoid of patient 8 , and also in specimens of the primary pancreatic gastrinomas and a lymph node metastasis of patient 9 (Table II).

\section{Clinical Results of Octreotide Treatment}

The clinical responses to octreotide $(0.15$ to 1.5 $\mathrm{mg} /$ day) were monitored in seven patients (Table II). Reductions of $25 \%$ to $100 \%$ in serum corticotropin or in urinary cortisol excretion, or both, could be demonstrated for all patients, except patient 6 . Recurrence of a corticotropin-producing bronchial carcinoid was suspected for patient 6 but not identified, and no significant suppression of the urinary secretion of cortisol was found even with high doses of octreotide ( $1.5 \mathrm{mg} /$ day intravenously).

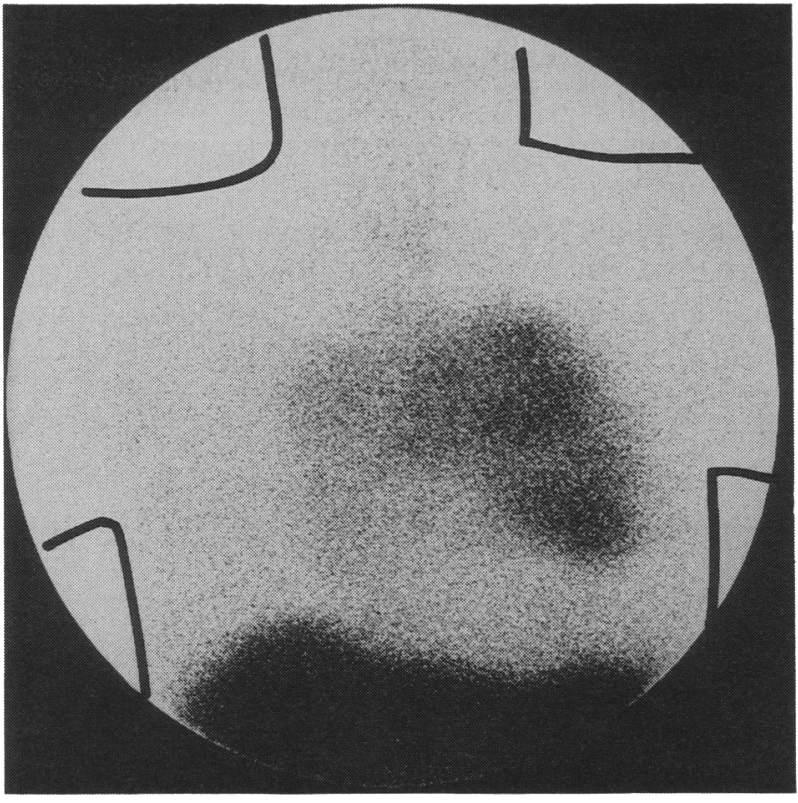

Figure 4. Anterior chest image of patient 8,24 hours after injection of ${ }^{111} \ln$-DTPA-D-Phe ${ }^{1}$-octreotide. Note the accumulation of radioactivity in the large mediastinal carcinoid tumor.

\section{Scintigraphic Evaluation of Control Patients}

Normal scans were obtained for eight patients with corticotropin-secreting pituitary tumors (five had Cushing's disease and three had Nelson's syndrome), and for one patient with Cushing's syndrome caused by a cortisol-secreting adrenal adenoma.

\section{COMMENTS}

Patients with the ectopic corticotropin secretion syndrome usually have obvious underlying tumors, most commonly neuroendocrine tumors ${ }^{1,2}$; however, as many as $30 \%$ of corticotropin-producing neuroendocrine tumors go undetected for a long time.,4 Because these occult neuroendocrine tumors may be potential malignancies, determined attempts at early localization must be made before metastases or local invasions prevent curative treatment. ${ }^{4}$ When evaluating patients with suspected ectopic corticotropin secretion, CT and MR imaging of the chest and abdomen are the best localization methods currently available. ${ }^{3,4,15}$ Even so, identifying a mass does not prove its function, and some tumors remain occult. Hence, a study that reveals both structure and function is needed, but the approaches tried thus far have met with limited success. Extensive selective venous catheterization and blood sampling is only occasionally successful in localizing an ectopic source ${ }^{2-4}$; and bilateral simultaneous petrosal sinus blood sampling helps exclude a pituitary source of Cushing's syndrome but does not localize the true source of corticotropin..$^{15}$ The results of our study suggest that somatostatin receptor scintigraphy is useful for identifiying ectopic sources of corticotropin and CRH. 
Abnormalities in the control of glucocorticoid secretion and elevated levels of corticotropin have been observed in as many as $30 \%$ of cases of small cell lung cancer, but they lead to clinically recognized Cushing's syndrome in fewer than $5 \%{ }^{16,17}$ Tumorous corticotropin production may occasionally dominale the clinical picture of patients with bronchial and thymic carcinoids. ${ }^{18-20}$ As many as $30 \%$ of gastrinomas contain corticotropin-like immunoreactivity, but the full-blown clinical picture of Cushing's syndrome occurs in approximately $8 \%$ of patients with these gastrinomas. ${ }^{21}$

A few cases of ectopic production of $\mathrm{CRH}$, with or without corticotropin, by medullary thyroid carcinomas and carcinoids have been reported in the literature. ${ }^{22,23}$ Corticotropin-releasing hormone stimulates corticotropin production from anterior pituitary cells, causing characteristics of Cushing's disease rather than the classical ectopic corticotropin syndrome. In these cases, catheterizing the petrosal sinus may falsely point to a diagnosis of Cushing's disease. Ectopic CRH secretion rather than corticotropin secretion by a metastatic medullary thyroid carcinoma was documented as the cause of Cushing's syndrome in patient 1. Bilateral simultaneous petrosal sinus blood sampling for corticotropin was not done for this patient, however, and pituitary MR imaging did not show abnormalities.

In vitro labeling of somatostatin analog-binding sites, as demonstrated by autoradiography using $\left[{ }^{125} \mathrm{I}-\right.$ Tyr ${ }^{3}$-octreotide, has been reported successful in 6 of 26 medullary thyroid carcinoma tumor samples,${ }^{24}$ in 4 of 7 small cell lung cancer samples and in none of 17 non-small cell lung cancer samples, ${ }^{25,26}$ in 54 of 62 samples from different carcinoid tumor localizations, ${ }^{27}$ and in 10 of 14 endocrine pancreatic tumor specimens. ${ }^{28}$

The radiopharmaceuticals $\left[{ }^{123} \mathrm{I}-\mathrm{Tyr}^{3}\right]$-octreotide and [111 In-DTPA-D-Phe $\left.{ }^{1}\right]$-octreotide are suitable compounds for in vivo localizing of somatostatin-receptorpositive tumors. ${ }^{10-14}$ For visualizing these tumors, [ ${ }^{111}$ In-DTPA-D-Phe $\left.{ }^{1}\right]$-octreotide seems superior to [ ${ }^{123}$ I$\mathrm{Tyr}^{3}$ ]-octreotide, especially when they are located in the upper part of the abdomen. A positive localization by in vivo somatostatin receptor scintigraphy correlates well with the presence of somatostatin analogbinding sites in vitro. ${ }^{8-10,14}$ To date, visualizing the primary medullary thyroid carcinoma and its metastases with radiolabeled octreotide has been successful in 11 of 17 patients in our clinic. ${ }^{10}$ Small cell lung cancers and their metastases were visualized in 5 of 8 patients, ${ }^{29}$ and primary carcinoids and their metastases were visualized in 32 of 37 patients. ${ }^{10}$ Metastatic gastrinomas have been demonstrated in all 12 patients studied by us so far. ${ }^{10}$ In our series of patients with ectopic corticotropin production, the primary tumor as well as most secondary tumor deposits were suc-

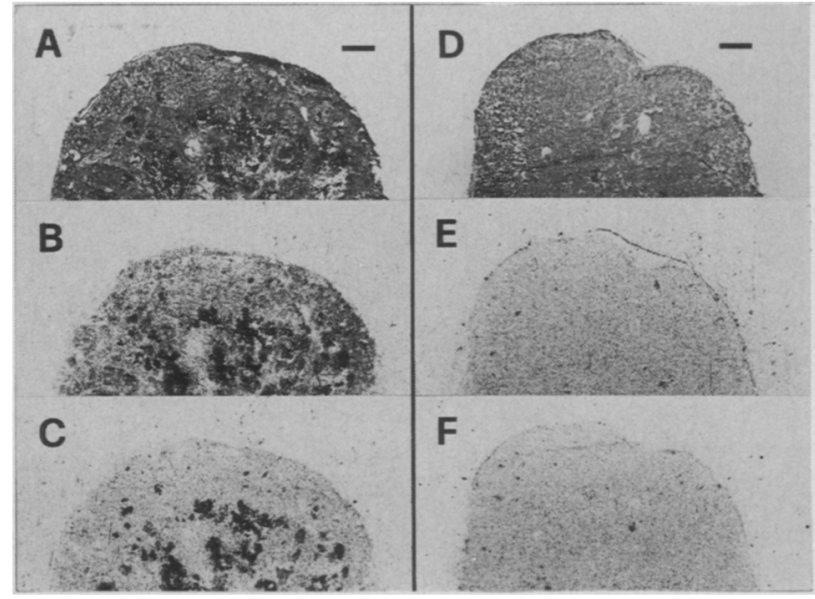

Figure 5. In vitro autoradiography of the lymph node metastases from the neck $(\mathbf{A}-\mathbf{C})$ and abdomen $(\mathbf{D}-\mathbf{F})$ from patient 1. Hematoxylin-eosin stained sections $(\mathbf{A}, \mathbf{D})$. Autoradiograms showing total binding of $\left.{ }^{1}{ }^{125} \mid-\mathrm{Tyr}^{3}\right]$-octreotide $(\mathbf{B}, \mathbf{E})$; note the labeling (black areas) in the lymph node metastasis from the neck (BC,F), which is absent in the abdominal lymph node metastasis (E). Nonspecific binding with $1 \mathrm{mmol} / \mathrm{L}\left[\right.$ Tyr $\left.^{3}\right]$-octreotide $(\mathbf{C}, \mathbf{F})$. $\mathrm{Bar}=1 \mathrm{~mm}$.

cessfully visualized in 8 of the 10 patients (Table II).

Successful control of ectopic corticotropin release by octreotide has been reported in patients with metastatic medullary thyroid carcinomas, ${ }^{30}$ lung carcinoids, ${ }^{31,32}$ and gastrinomas, ${ }^{33,34}$ although therapy failures have also been reported. ${ }^{35,36}$ In our series, a decrease - and in one case normalization-of plasma corticotropin concentration or urinary cortisol secretion, or both, in response to octreotide treatment was observed for six patients with somatostatin-receptor-positive tumors; no effects of octreotide therapy were observed for one patient with an occult corticotropin-producing tumor and negative octreotide scintigraphy. Thus, the receptor status of the tumor seems predictive for the corticotropin- and cortisollowering effects of octreotide.

Somatostatin receptor scintigraphy demonstrated uptake in the primary tumor and in the cervical lymph node metastases of a patient with metastatic medullary thyroid carcinoma, but not in the distant liver metastases nor in a retroperitoneal lymph node metastasis. Similarly, in vitro receptor autoradiography for somatostatin analog-binding sites was positive for the cervical lymph node metastasis sample, but negative for the liver metastasis sample. That suggests that the receptor-negative tumor localizations showed another degree of differentiation. Moreover, liver tumor localizations could not be detected in two other patients with metastatic medullary thyroid carcinoma; and in vivo somatostatin receptor imaging recognized the liver metastases in only 7 of $17 \mathrm{pa}-$ tients with medullary thyroid carcinoma and documented liver metastases. ${ }^{10,24,37}$ Presumably the normal accumulation of radioactivity in the liver prevents the detection of small metastases, which bind somato- 
statin to an extent similar to normal liver cell uptake of the radionuclide-coupled somatostatin analog. That means that somatostatin receptor scintigraphy should be combined with an ultrasound examination of the liver for patients with metastatic neuroendocrine tumors.

Our findings in the control group are in accordance with previous observations suggesting that corticotropin-secreting pituitary tumors and cortisol-producing adrenal adenomas are somatostatin receptor negative. . $^{710}$

Only four patients had potential occult ectopic corticotropin-secreting tumors (patients 4, 6, 7, and 10). Somatostatin receptor scintigraphy visualized the primary tumors as well as their metastases in three of these patients, but the tumor localization in one patient remains unknown. While these results are encouraging and suggest that somatostatin receptor scintigraphy may be useful for finding those clinically frustrating occult sources of corticotropin, more patients will need to be studied to determine the technique's true usefulness.

Scintigraphy with radiolabeled octreotide provides a new noninvasive technique for the in vivo detection of a variety of tumors, and [111In-DTPA-D-Phe ${ }^{1}$ ]-octreotide scintigraphy can be included as a diagnostic step in the workup of patients with Cushing's syndrome, especially when the diagnosis of ectopic corticotropin or CRH secretion is considered. We found a positive correlation between octreotide scintigraphy and the clinical response of Cushing's syndrome to octreotide therapy, but it must be realized that the drug therapy seldom completely controls adrenocortical hyperfunction in these patients.

\section{REFERENCES}

1. Odell WD. Ectopic ACTH secretion, a misnomer. Endocrinol Metab Clin $N$ Am. 1991;20:371-379.

2. Steingart DE. Ectopic secretion of peptides of the proopiomelanocortin family. Endocrinol Metab Clin N Am. 1991;20:453-471.

3. Doppman JL, Nieman L, Miller DL, et al. Ectopic adrenocorticotropic hormone syndrome: localization studies in 28 patients. Radiology. 1989; $172: 115-124$

4. Гindling JW, Tyrrell JB. Occult ectopic secretion of corticotropin. Arch Intern Med. 1985;146:929-933.

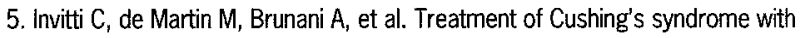
the long-acting somatostatin analogue SMS 201-995 (Sandostatin). Clin Endocrinol (Oxf). 1990;32:275-281.

6. Ambrosi B, Bochicchio D, Fadin C, et al. Failure of somatostatin and octreotide to acutely affect the hypothalamic-pituitary-adrenal function in patients with corticotropin hypersecretion. J Endocrinol invest. 1990; 13:257-261.

7. Lamberts SWJ, Uitterlinden P, Klijn JMG. The effect of the long-acting somatostatin analogue SMS 201-995 on ACTH secretion in Neison's syndrome and Cushing's disease. Acta Endocrinol (Copenh). 1989;120:760-766.

8. Krenning EP, Bakker WH, Breeman WAP, et al. Localisation of endocrinerelated tumours with radioiodinated analogue of somatostatin. Lancet. 1989;1:242-244.

9. Lamberts SWJ, Bakker WH, Reubi J-C, Krenning EP. Somatostatin-receptor imaging in the localization of endocrine tumors. NEJM. 1990;323:
1246-1249.

10. Lamberts SWJ, Krenning EP, Reubi J-C. The role of somatostatin and its analogs in the treatment of tumors. Endocr Rev. 1991;12:450-482.

11. Bakker WH, Krenning EP, Breeman WA, et al. Receptor scintigraphy with a radioiodinated somatostatin analogue: radiolabeling, purification, biological activity, and in vivo application in animals. J Nucl Med. 1990;71:1501-1509.

12. Bakker WI, Albert $R$, Bruns $C$, et al. [ ${ }^{111}{ }^{1}$ n-DTPA-D-Phe ${ }^{1}$-octreotide, a potential radiopharmaceutical for imaging of somatostatin receptor-positive tumors: synthesis, radiolabeling and in vitro validation. Life Sci. 1991;49:1583-1591.

13. Krenning EP, Bakker WH, Kooij PPM, et al. Somatostatin receptor scintigraphy with [nn-111DTPA-D-Phe']-octreotide in man: metabolism, dosimetry and comparison with [123|-Tyr ${ }^{3}$-octreotide. J Nucl Med. 1992;33:652-658.

14. Lamberts SWJ, Hofland $L$, van Koetsveld PM, et al. Parallel in vivo and in vitro detection of functional somatostatin receptors in human endocrine pancreatic tumors: consequences with regard to diagnosis, localization, and therapy. J Clin Endocrinol Metab. 1990;71:566-574.

15. Findling $J W$, Kehoe ME, Shaker $J$, Raff $H$. Routine inferior petrosal sinus sampling in the differential diagnosis of adrenocorticotropin (ACTH)-dependent Cushing's syndrome: early recognition of the occult ectopic ACTH syndrome. J Clin Endocrinol Metab. 1991;73:408-413.

16. Bondy PK, Gilby ED. Endocrine function in small cell undifferentiated lung cancer. Cancer. 1981;50:2147-2153.

17. Krauss S, Macy S, Ichiki AT. A study of immunoreactive calcitonin (CT), adrenocorticotropic hormone (ACTH) and carcinoembryonic antigen (CEA) in lung cancer and other malignancies. Cancer, 1981;47:2485-2492.

18. Pass HI, Doppman JL, Nieman L, et al. Management of ectopic ACTH syndrome due to thoracic carcinoids. Ann Thorac Surg. 1990;50:52-57.

19. Odell WD. Bronchial carcinoids and the ectopic ACTH syndrome. Ann Thorac Surg. 1990;50:5-6.

20. Limper AH, Carpenter PC, Scheithauer B, Staats BA. The Cushing syndrome induced by bronchial carcinoid tumors. Ann Intern Med. 1992;117:209-214.

21. Maton PN, Gardner JD, Jensen RT. Cushing's syndrome in patients with the Zollinger-Ellison syndrome. NEJM. 1986;315:1-5.

22. Tourniaire J, Rebattu B, Conte-Devolx B, et al. Syndrome de Cushing secondaire à la production ectopique de CRF par un carcinome médullaire du corps thyroïde. Ann Endocrinol (Paris). 1988;4:61-67.

23. Zarate $A$, Kovacs $K$, Flores $M$, et al. ACTH and CRF-producing bronchial carcinoid associated with Cushing's syndrome. Clin Endocrinol (Oxf). 1986;24:523-529.

24. Reubi $J-C$, Chayvialle $J A$, Franc $B$, et al. Somatostatin receptors and somatostatin content in medullary thyroid carcinomas. Lab invest. 1991; 84:567-573.

25. Reubi $J$ C, Waser B, Sheppard M, Macaulay V. Somatostatin receptors are present in small-cell but not in non-small-cell primary lung carcinomas: relationship to EGF-receptors. Int J Cancer. 1990:45:269-274.

26. Sagman U, Mullen JB, Kovacs $K$, et al. Identification of somatostatin receptors on human small cell lung carcinoma. Cancer. 1990;66:2129-2133. 27. Reubi $\mathcal{L} C$, Kvols $L K$, Waser $B$, et al. Detection of somatostatin receptors in surgical and percutaneous needle biopsy samples of carcinoids and islet cell carcinomas. Cancer Res. 1990;50:5960-5965.

28. Reubi J-C, Hacki WH, Lamberts SWJ. Hormone-producing gastrointestinal tumors contain a high density of somatostatin receptors. J Clin Endocrinol Metab. 1987;65:1127-1134.

29. Kwckkcboom DJ, Krenning EP, Bakker WH, et al. Radioiodinated somatostatin analog scintigraphy in small cell lung cancer. J Nucl Med. $1991 ; 32: 1845-1848$.

30. Ahlman $\mathrm{H}$, Tisell L-E. The use of a long-acting somatostatin analogue in the treatment of advanced endocrine malignancies with gastrointestinal symptoms. Scand J Gastroenterol. 1987;22:938-942.

31. Johansen K, Reid K, Woodhouse N. Acute ACTH-lowering effect of SM201995 (Sandostatin) in a patient with Cushing's syndrome due to ectopic ACTHproducilig lung carcinoid. Saudi Med J. 1988;9:512-514.

32. Hearn $P$, Reynolds $C L$, Johansen $K$, Woodhouse $N$ J. Lung carcinoid with Cushing's syndrome: control of serum ACTH and cortisol levels using SMS 201-995 (Sandostatin). Clin Endocrinol (Oxf). 1988;28:181-185. 
33. Ruszniewski $P$, Girard F, Benamouzig R, Mignon M. Long acting somatostatin treatment of paraneoplastic Cushing's syndrome in a case of Zollinger-Ellison syndrome. Gut. 1988;29:838-842.

34. Bertagna $X$, Favrod-Coune $C$, Escourolle $H$, et al. Suppression of ectopic adrenocorticotropin secretion by the long-acting somatostatin analog otcreotide. J Clin Endocrinol Metab. 1989;68:988-991.

35. Burrell L, Gray CE, Thomson JA. Failure of somatostatin analogue SMS
201-995 to control Cushing's syndrome due to ectopic release of ACTH from a bronchial carcinoid. Scot Med J. 1989;34:533-534.

36. Cheung NW, Boyages SC. Failure of somatostatin analogue to control Cushing's syndrome in two cases of ACTH-producing carcinoid tumours. Clin Endocrinol (Oxf). 1992;36:361-367.

37. Kwekkeboom DJ, Reubi JC, Lamberts SWJ, et al. In vivo receptor imaging in medullary thyroid carcinoma. J Clin Endocrinol Melab. 1993;76:1413-1417. 